\title{
Effective Use of Biomass Wastes for Removing Hazardous Inorganic Ions from Aquatic Environment
}

\author{
Katsutoshi Inoue*, Hidetaka Kawakita and Keisuke Ohto \\ Department of Applied Chemistry, Saga University, Japan \\ Submitted: December 22, 2017; Published: January 11, 2018 \\ *Corresponding author: Katsutoshi Inoue, Department of Applied Chemistry, Saga University, Honjo 1, Saga 840-8502, Japan, Tel: +81 905290 \\ 7575; E-mail: kanoko1921@gmail.com
}

\begin{abstract}
Trace concentrations of hazardous inorganic anionic species such as arsenate, phosphate, antimonite, selenite and fluoride can be effectively and selectively removed from water by means of adsorption using the gels prepared from biomass wastes such as orange juice residue loaded with multi-valent metal ions such as zirconium (IV). The adsorption capacities of these gels for arsenic are much higher than other adsorbents reported in literatures.
\end{abstract}

\section{Introduction}

In recent years, pollution of water by various toxic materials has become serious all over the world especially in developing countries, caused by the development of industries in these countries. Among toxic materials, although mercury and lead are the most toxic, arsenic and fluorine are also toxic. Especially, pollution of underground water by arsenic in Bangladesh and India is well known. Although mercury and lead exist as cationic species in aquatic environments, majority of toxic inorganic materials exist as anionic species. For example, arsenic (III and $\mathrm{V}$ ) exists oxo-anions such as arsenite $\left(\mathrm{AsO}_{3}{ }^{3-}\right)$ and arsenate $\left(\mathrm{AsO}_{4}{ }^{3-}\right)$, respectively. To avoid the pollution by these toxic elements, severe standards are required for effluents from industries in each country. For example, the typical standards in Japan are as follows; chromium (VI): 0.5, selenium: 0.1, arsenic: 0.1 , flourine: 8 (unit; $\mathrm{mg} / \mathrm{dm}^{3}$ ). To clear these standards, various techniques have been developed to date and some of them have been commercialized. The typical techniques are precipitation, electrochemical treatments, Donnan dialysis, ion exchange and adsorption. However, these conventional techniques are suffering from some drawbacks such as poor selectivity, high operation costs and so forth.

These toxic anionic species exist in trace concentrations in water together with excess concentrations of non-toxic anionic species such as carbonate and sulfate. Consequently, it is important to selectively remove these toxic anionic species over the non-toxic anionic species; i.e. the selectivity to the anionic species in question over other anionic species is the most important. Among the above-mentioned techniques, adsorption technique including ion exchange is the most suitable for removing trace concentration of hazardous materials. However, the majority of adsorbents suffer from low selectivity to the species in question. It is difficult to selectively adsorb the abovementioned anionic species using usual anion exchange materials such as commercially available anion exchange resins according to the well known Hoffmeister's selectivity series among anionic species [1]. For the adsorptive removal of these anionic species, the use of cation exchange materials such as strongly acidic cation exchange resins loaded with high-valent metal cations such as ferric ions exhibiting a high affinity for the anionic species in question has been proposed [2]. However, ion exchange resins suffer from another problem in case they are used for solutions containing fine solid particles or solid suspension; that is; these fine solid particles easily enter into micro-pores of ion exchange resins and clog the pores, impeding the smooth operation of adsorption.

We hit upon an idea to use some biomass wastes instead of synthetic ion exchange resins to effectively and selectively adsorb hazardous anionic species of arsenic [3,4], phosphorus [5,6], antimony [7], selenium [8] and fluorine [9-12]. The candidate biomass wastes are orange and apple juice residues and seaweeds wastes containing large amounts of functional groups of carboxylic acid; i.e. orange and apple juice residues contain pectic acid while sea-weeds contain alginic acid, the chemical structures of which are shown in Scheme 1. In this review article, we introduce the adsorptive removal of arsenic using the adsorption gel of orange juice residue as a typical example. 


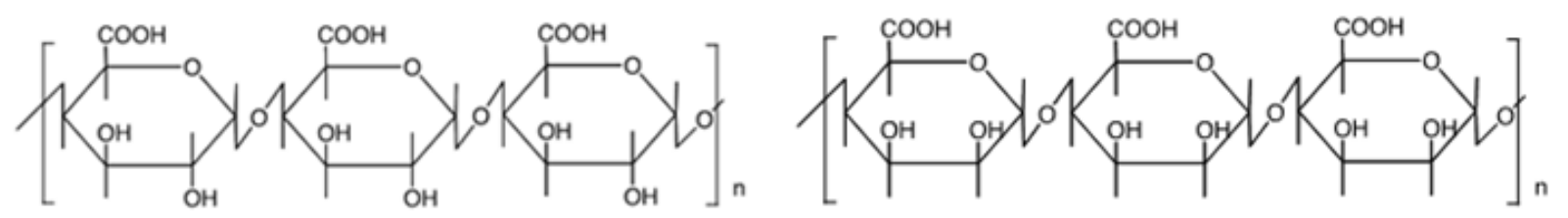

Scheme 1: Chemical structures of pectic acid (left) and alginic acid (right).

\section{Mechanism of adsorption of toxic anionic species on metal-loaded biomass wastes}

Cationic metal ions such as lead (II) and iron (III) are adsorbed on pectic acid and alginic acid by cation exchange reaction forming stable five-membered chelates as shown in Scheme 2; i.e. these polysaccharides function as natural chelating polymeric materials. In the case of adsorption of divalent metal ions such as copper (II) and lead (II), all of 2 positive charges of these metal ions may be neutralized by 2 carboxylic groups of these polysaccharides. However, in the case of trivalent and tetravalent metal ions such as ferric ion and zirconium ion which exhibit high affinity for the above-mentioned hazardous anionic species, it is difficult for all of these positive charges to be neutralized by the carboxylic acid functional groups due to strong steric hindrance of these polymeric materials [13-20]. The positive charges which are not neutralized by the carboxylic acid functional groups are neutralized by hydroxyl ions in water and these hydroxyl ions are substituted by the hazardous anionic species (Scheme 2).

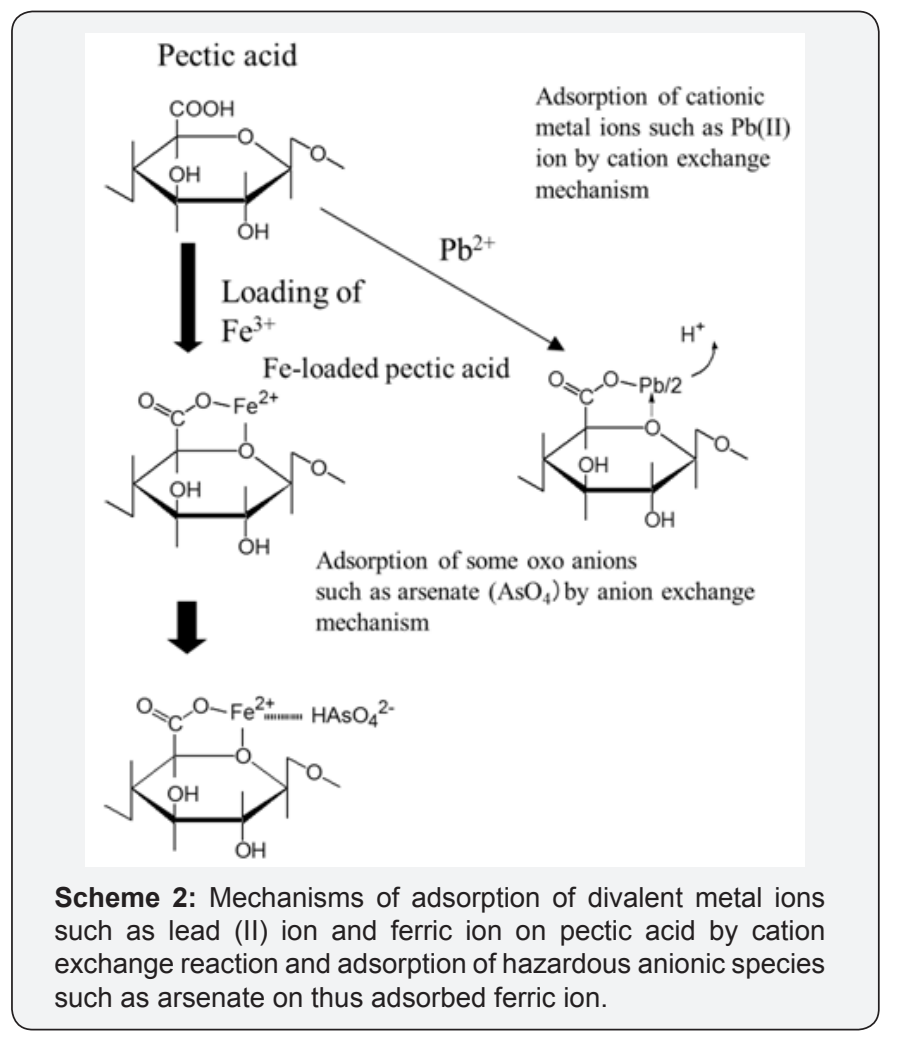

Among the tested multi-valent metal ions loaded on orange juice residue, zirconium (IV) ion was found to be the most suitable metal ion to absorb the above-mentioned anionic species. As a typical example, Table 1 shows the comparison of maximum adsorption capacities for arsenic (V and III) by zirconium (IV)loaded orange juice residue gel and by other adsorbents reported in literatures. As can be seen from this table, the zirconium (IV)loaded orange juice residue gel exhibit much higher adsorption than other adsorbents including the zirconium (IV)-loaded synthetic chelating resin. It was also verified that the adsorption gels of orange juice residue and waste sea-weed can effectively remove trace concentration of arsenic from actual acid mine drainage [21].

Table 1: Concentration of arsenic from actual acid mine drainage.

\begin{tabular}{|c|c|c|c|}
\hline Adsorbent & $\begin{array}{c}\text { Arsenic } \\
\text { species }\end{array}$ & $\begin{array}{c}\text { Maximum adsorption } \\
\text { capacity (mol kg-1) }\end{array}$ & Reference \\
\hline $\begin{array}{c}\text { Zr(IV)-loaded } \\
\text { orange juice residue } \\
\text { gel }\end{array}$ & $\mathrm{As}(\mathrm{V})$ & 1.05 & {$[4]$} \\
\hline Activated carbon & $\mathrm{As}(\mathrm{V})$ & 0.014 & {$[13]$} \\
\hline $\begin{array}{c}\mathrm{La} \text { (III)-impregnated } \\
\text { alumina }\end{array}$ & $\mathrm{As}(\mathrm{V})$ & 0.171 & {$[14]$} \\
\hline $\begin{array}{c}\mathrm{Ce}(\mathrm{IV})-\text { doped iron } \\
\text { oxide }\end{array}$ & $\mathrm{As}(\mathrm{V})$ & 0.213 & {$[15]$} \\
\hline $\begin{array}{c}\mathrm{Zr}(\mathrm{IV})-\text {-loaded LDA } \\
\text { chelating resin }\end{array}$ & $\mathrm{As}(\mathrm{V})$ & 0.655 & {$[16]$} \\
\hline $\begin{array}{c}\text { Lessonianigrescens, } \\
\text { an algae }\end{array}$ & $\mathrm{As}(\mathrm{V})$ & 0.376 & {$[17]$} \\
\hline $\begin{array}{c}\text { Zr(IV)-loaded } \\
\text { orange juice residue } \\
\text { gel }\end{array}$ & $\mathrm{As}(\mathrm{III})$ & 1.60 & {$[4]$} \\
\hline $\begin{array}{c}\text { Fe(III)-loaded LDA } \\
\text { chelating resin }\end{array}$ & $\mathrm{As}(\mathrm{III})$ & 0.839 & {$[18]$} \\
\hline $\begin{array}{c}\text { Iron oxide coated } \\
\text { cement }\end{array}$ & $\mathrm{As}(\mathrm{III})$ & 0.0092 & {$[19]$} \\
\hline Sorghum biomass & $\mathrm{As}(\mathrm{III})$ & 0.048 & {$[20]$} \\
\hline
\end{tabular}

\section{Conclusion}

Adsorption gels effective for removing trace concentration of hazardous anionic species such as arsenate, arsenite, phosphate and fluoride were prepared from orange juice residue and seaweed wastes in a simple manner. The adsorption capacities of these adsorption gels were higher than other adsorbents so far reported. It can be expected that these adsorbents are 
successfully applied for actual waste solutions containing these hazardous anionic species.

\section{References}

1. Helfferich F (1962) Ion Exchange, McGraw-Hill, New York, USA.

2. Yoshida I, Ueno K, Kobayashi H (1978) Selective separation of arsenic (III) and (V) ions with ferric complex of chelating ion-exchange resin. Sep Sci Technol 13(2): 173-184.

3. Biswas BK, Inoue K, Ghimire KN, Kawakita H, Ohto K, et al. (2008) Effective removal of arsenic with lanthanum (III)- and cerium (III)loaded orange waste gels. Sep Sci Technol 43(8): 2144-2165.

4. Biswas BK, Inoue J, Inoue K, Ghimire KN, Harada H, et al. (2008) Adsorptive removal of As (V) and As(III) from water by a $\mathrm{Zr}(\mathrm{IV})$-loaded orange waste gel. J Hazard Mater 154: 1066-1074.

5. Biswas BK, Inoue K, Ghimire KN, Ohta S, Harada H, et al. (2007) The adsorption of phosphate from an aquatic environment using metalloaded orange waste. Coll Int Sci 312(2): 214-223.

6. Biswas BK, Inoue K, Ghimire KN, Harada H, Ohto K, et al. (2008) Removal and recovery of phosphorus from water by means of adsorption onto orange waste gel loaded with zirconium. Biores Technol 99(18): 86858690.

7. Biswas BK, Inoue J, Kawakita H, Ohto K, Inoue K (2009) Effective removal and recovery of antimony using metal-loaded saponified orange waste. J Hazard Mater 172(2-3): 721-728.

8. Biswas BK, Inoue K, Kawakita H, Harada H, Ohto K, et al. (2010) Study of $\mathrm{Zr}^{\mathrm{IV}}$-loaded orange waste gel for selenate adsorption. J Wat Environ Technol 8: 313-320.

9. Paudyal H, Pangeni B, Inoue K, Kawakita H, Ohto K, et al. (2011) Adsorptive removal of fluoride from aqueous solution using orange waste loaded with multi-valent metal ions. J Hazard Mater 192(2): 676-682.

10. Paudyal H, Pangeni B, Inoue K, Matsueda M, Suzuki R, et al. (2012) Adsorption behavior of fluoride ions on zirconium (IV)-loaded orange waste gel from aqueous solution. Sep Sci Technol 47(1): 96-103.
11. Paudyal H, Pangeni B, Ghimire KN, Inoue K, Ohto K, et al. (2012) Adsorption behavior of orange waste gel for some rare earth ions and its application to the removal of fluoride from water. Chem Eng J 195196: $289-296$

12. Paudyal H, Pangeni B, Inoue K, Kawakita H, Ohto K, et al. (2013) Preparation of novel alginate based anion exchanger from Ulva japonica and its application for the removal of trace concentrations of fluoride from water. Biores Technol 148: 221-227.

13. Gupta SK, Chen KY (1978) Arsenic removal by adsorption. J Wat Pol Cont Fed 50: 493-506.

14. Wasay SA, Tokunaga S, Park SW (1996) Removal of hazardous anions from aqueous solutions by La(III) and Y(III)-impregnated alumina. Sep Sci Technol 31(10): 1501-1514.

15. Zhang Y, Yang M, Huang X (2003) Arsenic (V) removal with a Ce (IV)doped iron oxide adsorbent. Chemosphere 51(9): 945-952.

16. Balaji T, Yokoyama T, Matsunaga $H$ (2005) Adsorption and removal of As (V) and As (III) using Zr-loaded lysine diacetic acid chelating resin. Chemosphere 59(8): 1169-1174.

17. Hansen HK, Ribeiro A, Mareus E (2006) Biosorption of arsenic (V) with Lessonianigrescens. Miner Eng 19(5): 486-490.

18. Matsunaga H, Yokoyama T, Eldridge RJ, Bolto BA (1996) Adsorption characteristics of arsenic (III) and arsenic (V) on iron (III)-loaded chelating resin having lysine-N, N-diacetic acid moiety. React Func Polym 29(3): 167-174.

19. Kundu S, Gupta AK (2007) Adsorption characteristics of As (III) from aqueous solution on iron oxide coated cement. J Hazard Mater 142(12): 464-479.

20. Haque MN, Morrison GM, Perrusquia G, Gutierrez M, Aguilera AF, et al. (2007) Characteristics of arsenic adsorption to sorghum biomass. J Hazard Mater 145(1-2): 30-35

21. Inoue K, Ghimire KN, Hayashida T, Oshima T, Ohto K, et al. (2003) Removal of arsenic from mine water by the effective use of biomass. Shigen to Sozai (J Min Mater Process Inst Japan) 119(12): 767-771.

\begin{tabular}{l} 
Your next submission with Juniper Publishers \\
will reach you the below assets \\
- Quality Editorial service \\
- Swift Peer Review \\
- Reprints availability \\
- E-prints Service \\
- Manuscript Podcast for convenient understanding \\
- Global attainment for your research \\
- Manuscript accessibility in different formats \\
( Pdf, E-pub, Full Text, Audio) \\
- Unceasing customer service \\
Track the below URL for one-step submission \\
https://juniperpublishers.com/online-submission.php \\
\hline
\end{tabular}

